\title{
Iron-bound organic carbon in forest soils: quantification and characterization
}

\author{
Qian Zhao $^{1}$, Simon R. Poulson ${ }^{2}$, Daniel Obrist ${ }^{3}$, Samira Sumaila ${ }^{4,5}$, James J. Dynes ${ }^{4}$, Joyce M. McBeth ${ }^{4,5}$, and \\ Yu Yang ${ }^{1}$ \\ ${ }^{1}$ Department of Civil and Environmental Engineering, University of Nevada, Reno, Nevada, 89557, USA \\ ${ }^{2}$ Department of Geological Sciences and Engineering, University of Nevada, Reno, Nevada, 89557, USA \\ ${ }^{3}$ Division of Atmospheric Sciences, Desert Research Institute, Reno, Nevada, 89512, USA \\ ${ }^{4}$ Canadian Light Source, 44 Innovation Blvd, Saskatoon, SK, S7N 2V3, Canada \\ ${ }^{5}$ Department of Geological Sciences, University of Saskatchewan, Saskatoon, SK, S7N 5E2, Canada \\ Correspondence to: Yu Yang (yuy@unr.edu)
}

Received: 16 November 2015 - Published in Biogeosciences Discuss.: 25 January 2016

Revised: 16 July 2016 - Accepted: 27 July 2016 - Published: 24 August 2016

\begin{abstract}
Iron oxide minerals play an important role in stabilizing organic carbon (OC) and regulating the biogeochemical cycles of $\mathrm{OC}$ on the earth surface. To predict the fate of OC, it is essential to understand the amount, spatial variability, and characteristics of Fe-bound $\mathrm{OC}$ in natural soils. In this study, we investigated the concentrations and characteristics of Fe-bound OC in soils collected from 14 forests in the United States and determined the impact of ecogeographical variables and soil physicochemical properties on the association of $\mathrm{OC}$ and $\mathrm{Fe}$ minerals. On average, Fe-bound OC contributed $37.8 \%$ of total OC (TOC) in forest soils. Atomic ratios of $\mathrm{OC}$ : Fe ranged from 0.56 to 17.7 , with values of 1-10 for most samples, and the ratios indicate the importance of both sorptive and incorporative interactions. The fraction of Fe-bound OC in TOC $\left(f_{\mathrm{Fe}-\mathrm{OC}}\right)$ was not related to the concentration of reactive $\mathrm{Fe}$, which suggests that the importance of association with $\mathrm{Fe}$ in $\mathrm{OC}$ accumulation was not governed by the concentration of reactive Fe. Concentrations of Fe-bound $\mathrm{OC}$ and $f_{\mathrm{Fe}-\mathrm{OC}}$ increased with latitude and reached peak values at a site with a mean annual temperature of $6.6^{\circ} \mathrm{C}$. Attenuated total reflectance-Fourier transform infrared spectroscopy (ATR-FTIR) and near-edge $\mathrm{X}$-ray absorption fine structure (NEXAFS) analyses revealed that $\mathrm{Fe}$-bound $\mathrm{OC}$ was less aliphatic than non-Fe-bound OC. $\mathrm{Fe}$-bound $\mathrm{OC}$ also was more enriched in ${ }^{13} \mathrm{C}$ compared to the non-Fe-bound $\mathrm{OC}$, but $\mathrm{C} / \mathrm{N}$ ratios did not differ substantially. In summary, ${ }^{13} \mathrm{C}$-enriched $\mathrm{OC}$ with less aliphatic carbon and more carboxylic carbon was associated with $\mathrm{Fe}$
\end{abstract}

minerals in the soils, with values of $f_{\mathrm{Fe}-\mathrm{OC}}$ being controlled by both sorptive and incorporative associations between $\mathrm{Fe}$ and OC. Overall, this study demonstrates that Fe oxides play an important role in regulating the biogeochemical cycles of $\mathrm{C}$ in forest soils and uncovers the governing factors for the spatial variability and characteristics of Fe-bound OC.

\section{Introduction}

Soil organic carbon (OC) in forests is a vital component of C biogeochemical cycles (Eswaran et al., 1999). Global warming can potentially accelerate the decomposition of forest soil OC, contributing to greenhouse gas emissions (Steffen et al., 1998). Alternatively, forest soils can act as strong sinks for $\mathrm{OC}$, if appropriate management is implemented, such as forest harvesting and fire treatment (Eswaran et al., 1999; Johnson and Curtis, 2001). Understanding the fate and stability of forest $\mathrm{OC}$ is important for evaluating and managing the global $\mathrm{C}$ cycle under the framework of climate change.

Currently, there is an information gap concerning the stability and residence time of OC, contributing to the problem that the residence time of OC (ranging from months to hundreds of years) is a major source of uncertainty in modeling and prediction of $\mathrm{C}$ cycles (Schmidt et al., 2011; Riley et al., 2014). Many concepts have been proposed to account for OC stabilization and therefore residence times, including molecular recalcitrance, physical occlusion, and chemical protec- 
tion (Sollins et al., 1996; Krull et al., 2003; Baldock et al., 2004; Mayer et al., 2004; Zimmerman et al., 2004; Schmidt et al., 2011). In general, the stability of OC is regulated by biogeochemical reactions occurring at the interfaces between OC, minerals, and microorganisms, and further knowledge about the mechanism for OC stabilization is critical for building up process-based models to simulate and predict $\mathrm{C}$ cycles.

A number of lines of evidence suggest a key importance of iron oxide minerals in the stabilization of OC (Kalbitz et al., 2005; Kaiser and Guggenberger, 2007; Wagai and Mayer, 2007). Iron ( Fe) oxides have a relatively high sorption capacity for OC, with sorption coefficients for OC much higher than that of other metal oxides (Kaiser and Guggenberger, 2007; Chorover and Amistadi, 2001). Wagai and Mayer (2007) reported Fe-bound OC concentrations in soils up to $22 \mathrm{mg} \mathrm{g}^{-1}$ soil, contributing up to $40 \%$ of total OC (TOC) for most forest soils. Similarly, Lalonde et al. (2012) found that Fe-bound OC contributed $22 \%$ of TOC in sediments. Studies have shown that $\mathrm{Fe}$ minerals protect $\mathrm{OC}$ from degradation and inhibit mineralization of OC (Baldock and Skjemstad, 2000; Kalbitz et al., 2005). There is, however, no systematic study on the occurrence of Fe-bound OC across different forests and its governing factors.

The overall goals of this study were to investigate the spatial variability of Fe-bound OC across forest soils, the factors that control Fe-bound OC concentrations, and the characteristics of Fe-bound OC with respect to the physicochemical properties of soils. In this study, we first quantified the concentration of Fe-bound OC across 14 forest soils in the United States and analyzed the spatial distribution and influences of ecogeographical factors. Second, we investigated the impact of soil physicochemical properties on the Fe-OC associations. Third, we studied molecular characteristics of Fe-bound $\mathrm{OC}$ vs. non-Fe-bound $\mathrm{OC}$, including how $\mathrm{Fe}-\mathrm{OC}$ association influenced the chemical properties of $\mathrm{OC}$ and the stable isotope composition. Hence, this study provided a systematic evaluation for the Fe-bound OC in United States forests, the influences of ecological factors on the occurrence of Fe-bound $\mathrm{OC}$, and the effects of association with $\mathrm{Fe}$ on the chemical properties of OC.

\section{Methods and materials}

\subsection{Chemicals and materials}

Reagents used for Fe reduction experiments include sodium bicarbonate $\left(\mathrm{NaHCO}_{3}\right.$ : Sigma-Aldrich, St. Louis, MO, USA), trisodium citrate dihydrate $\left(\mathrm{Na}_{3} \mathrm{C}_{6} \mathrm{H}_{5} \mathrm{O}_{7} \quad 2 \mathrm{H}_{2} \mathrm{O}\right.$ : Acros Organics, NJ, USA), and sodium dithionite $\left(\mathrm{Na}_{2} \mathrm{~S}_{2} \mathrm{O}_{4}\right.$ : Alfa Aesar, Ward Hill, MA, USA). All chemicals used were analytical grade.

\subsection{Soil sample collection, primary characterization and pretreatment}

Soil samples were collected from 14 forest sites in the United States (Obrist et al., 2011, 2015; Obrist, 2012). The abbreviations and the basic information for the sites are summarized in Table 1. More detailed information on the sites and sampling protocols can be found in previous publications (Obrist et al., 2011, 2015; Obrist, 2012). Briefly, two replicate plots at each forest site were sampled. During 2007-2009, topsoils $(0-20 \mathrm{~cm})$ from all sites were collected using clean latex gloves and stainless steel sampling equipment. All the samples were immediately transferred to plastic freezer bags and kept on ice before transportation to the laboratory. Soil texture was analyzed by an ASTM 152-type hydrometer at the Soil Forage and Water Analysis Laboratory at Oklahoma State University (Obrist et al., 2011). The soil pH was measured by mixing soil particle with deionized (DI) water in a solid/ solution ratio of $1: 1$ (Kalra et al., 1995). Soil samples used in the experiments in this study were ground to $<500 \mu \mathrm{m}$ and freeze-dried after the removal of roots and visible plant material and large particles $(>2 \mathrm{~mm})$ by dry sieving.

\subsection{Total C (TC), TOC and stable C isotope analyses}

TC, TOC and stable C isotopic compositions of soil samples were analyzed using a Eurovector elemental analyzer (Eurovector SPA, Milan, Italy) interfaced to a Micromass IsoPrime stable isotope ratio mass spectrometer (Micromass UK Ltd., Manchester, UK). Acetanilide (71.09\% C by weight) was used as a standard compound to establish a calibration curve between mass of $\mathrm{C}$ and the $m / z 44$ response from the mass spectrometer. In this study, the concentration of TC and TOC were expressed as weight percent. Stable C isotope analyses were performed after the method of Werner et al. (1999), with results reported in the usual delta notation in units of \%ovs. Vienna Pee Dee Belemnite (VPDB). For TOC analysis, soil samples were acidified with $1 \mathrm{M} \mathrm{HCl}$ with the solution / solid ratio of $1 \mathrm{~mL}$ solution $/ 0.5 \mathrm{~g}$ soil and heated at $10{ }^{\circ} \mathrm{C}$ for $1 \mathrm{~h}$. The treatment was repeated three times until there was no further effervescence upon acid addition, after which the samples were dried and analyzed. All analyses are based on standard curves with $R^{2}>0.99$. The detection limit for $\mathrm{C}$ is $0.2 \mathrm{mg} \mathrm{g}^{-1}$ soil. The average coefficient of variation for the analysis of $\mathrm{C}$ is $20.2 \%$. 
Table 1. Information for the 14 forest sites studied (Obrist et al., 2011, 2015; Obrist, 2012).

\begin{tabular}{|c|c|c|c|c|c|c|c|c|c|c|}
\hline Forest ID & Abbr. & Location & $\begin{array}{l}\text { Soil order } \\
\text { (US) }\end{array}$ & $\begin{array}{l}\text { Soil class }{ }^{\mathrm{a}} \\
\text { (FAO) }\end{array}$ & Climate zone & $\begin{array}{l}\text { Lat } \\
\left({ }^{\circ}\right)^{\mathrm{b}}\end{array}$ & $\begin{array}{l}\text { Long } \\
\left({ }^{\circ}\right)^{\mathrm{c}}\end{array}$ & $\begin{array}{l}\text { Elevation } \\
\text { (ma.s.1.) }\end{array}$ & $\begin{array}{r}\text { Precip. }^{\mathrm{d}} \\
\left(\mathrm{mm} \mathrm{yr}^{-1}\right)\end{array}$ & $\begin{array}{r}\text { Temp. }{ }^{\mathrm{e}} \\
\left({ }^{\circ} \mathrm{C}\right)\end{array}$ \\
\hline Gainesville & GS & Gainesville, Florida & Spodosols & Podzols & Humid subtropical & 29.74 & -82.22 & 50 & 1228 & 21.7 \\
\hline Oak Ridge & OR & Oak Ridge, Tennessee & Ultisols & Acrisols & Humid subtropical & 35.97 & $-84,28$ & 325 & 1350 & 14.5 \\
\hline Ashland & $\mathrm{AL}$ & Ashland, Missouri & Alfisols & $\begin{array}{l}\text { Luvisols \& } \\
\text { Greyzems }\end{array}$ & Humid continental & 38.73 & -92.20 & 210 & 1023 & 13.9 \\
\hline $\begin{array}{l}\text { Little Valley } \\
\text { (post-fire) }\end{array}$ & LVF & Little Valley, Nevada & Entisols & Arenosols & Highland climate & 39.12 & -119.93 & 2010 & 551 & 5.0 \\
\hline Little Valley & LV & Little Valley, Nevada & Entisols & Arenosols & Highland climate & 39.12 & -119.93 & 2011 & 550 & 5.0 \\
\hline Marysville & MS & Marysville, California & Mollisols & Luvisols & Mediterranean climate & 39.25 & -121.28 & 386 & 775 & 16.9 \\
\hline Truckee (post-fire) & TKF & Truckee, California & Alfisols & Luvisols & Highland climate & 39.37 & -120.1 & 1768 & 569 & 6.0 \\
\hline Truckee & TK & Truckee, California & Alfisols & Luvisols & Highland climate & 39.37 & -120.1 & 1767 & 568 & 5.9 \\
\hline Niwot Ridge & NR & Niwot Ridge, Colorado & Alfisols & Cambisols & Highland climate & 40.03 & -105.55 & 3050 & 800 & 1.3 \\
\hline Hart & HT & Hart, Michigan & Spodosols & Podzols & Humid continental & 43.67 & -86.15 & 210 & 812 & 7.6 \\
\hline Bartlett & BL & Bartlett, New Hampshire & Spodosols & $\begin{array}{l}\text { Podzols \& } \\
\text { Lithosols }\end{array}$ & Humid continental & 44.0 & -71.29 & 272 & 1300 & 4.5 \\
\hline Howland & HL & Howland, Maine & Spodosols & Luvisols & Humid continental & 45.20 & -68.74 & 60 & 1040 & 6.7 \\
\hline Thompson I & TSI & Ravensdale, Washington & Inceptisols & Cambisols & Highland climate & 47.38 & -121.93 & 221 & 1141 & 9.8 \\
\hline Thompson II & TSII & Ravensdale, Washington & Inceptisols & Cambisols & Highland climate & 47.38 & -121.93 & 220 & 1140 & 9.8 \\
\hline
\end{tabular}

${ }^{\mathrm{a}}$ Food and Agriculture Organization. ${ }^{\mathrm{b}}$ Latitude. ${ }^{\mathrm{c}}$ Longitude. ${ }^{\mathrm{d}}$ Annual mean precipitation. ${ }^{\mathrm{e}}$ Annual mean temperature.

\subsection{Nitrogen $(\mathrm{N})$ analysis}

The $\mathrm{N}$ concentration of each sample was analyzed using a Eurovector elemental analyzer. Acetanilide $(10.36 \% \mathrm{~N}$ by weight) was used as a standard compound to establish a calibration curve between mass of $\mathrm{N}$ and the response of the thermal conductivity detector in the elemental analyzer. Total $\mathrm{N}$ and non-Fe-bound $\mathrm{N}$ concentrations were measured before and after a Fe reduction release treatment for each sample. All analyses are based on standard curves with $R^{2}>0.99$. The detection limit for $\mathrm{N}$ is $0.2 \mathrm{mg} \mathrm{g}^{-1}$ soil. The average coefficient of variation for the analysis of $\mathrm{N}$ is $20.5 \%$.

\subsection{Analysis of Fe-bound OC}

The concentration of Fe-bound OC was quantified by an established Fe reduction release method, commonly known as DCB extraction involving sodium dithionite, citrate and bicarbonate (Mehra and Jackson, 1960; Wagai and Mayer, 2007; Lalonde et al., 2012). The DCB extraction is assumed to extract most free Fe oxides (i.e., goethite, hematite, ferrihydrite and others) existing in soils, but should not extract structural Fe in clay minerals (Mehra and Jackson, 1960; Wagai and Mayer et al., 2007; Lalonde et al., 2012). In this study, we followed the specific protocol detailed in Lalonde et al. (2012). An aliquot $(0.25 \mathrm{~g})$ of soil was mixed with $15 \mathrm{~mL}$ of buffer solution at $\mathrm{pH} 7$ (containing $0.11 \mathrm{M}$ bicarbonate and $0.27 \mathrm{M}$ trisodium citrate) and then heated to $80^{\circ} \mathrm{C}$ in a water bath. The reducing agent sodium dithionite was added to the samples with a final concentration of $0.1 \mathrm{M}$ and maintained at $80^{\circ} \mathrm{C}$ for $15 \mathrm{~min}$. The samples were then centrifuged at $10000 \mathrm{rpm}$ for $10 \mathrm{~min}$, the supernatant was removed, and the residual particles were rinsed using $5 \mathrm{~mL}$ of DI water. The rinse-centrifuge process was performed three times. The residual particles were freeze-dried and analyzed for TC and TOC concentrations and $\delta^{13} \mathrm{C}$ composition. The mass of residual particles was used to calculate the OC concentration associated with non-Fe minerals.

The background release of $\mathrm{OC}$ during the heating process was measured following the method in Lalonde et al. (2012), where sodium citrate and dithionite were replaced by sodium chloride with the same ionic strength. An aliquot $(0.25 \mathrm{~g})$ of dry soil was mixed with $15 \mathrm{~mL}$ of $1.6 \mathrm{M} \mathrm{NaCl}$ and $0.11 \mathrm{M}$ $\mathrm{NaHCO}_{3}$, and heated to $80^{\circ} \mathrm{C}$. Then $0.22 \mathrm{~g}$ of $\mathrm{NaCl}$ was added, and the solution was maintained at $80^{\circ} \mathrm{C}$ for $15 \mathrm{~min}$. The samples were then centrifuged at $10000 \mathrm{rpm}$ and rinsed three times, and freeze-dried before analysis. The mass of residual particles was used to calculate the concentration of $\mathrm{OC}$ released by heating to $80^{\circ} \mathrm{C}$. In preliminary experiments, we found that the solution $\mathrm{pH}$ increased rapidly during the heating-extraction process with bicarbonate and sodium chloride only, and the increased $\mathrm{pH}$ values facilitated the release of additional OC. Hence, we used a lower initial $\mathrm{pH}$ of 6 to compensate for the shift to higher $\mathrm{pH}$ during heating. To validate the measurement for the concentration of OC released during heating, we also tested the release of OC using a phosphate buffer (same ionic strength) in lieu of the bicarbonate buffer, which can maintain a $\mathrm{pH}$ of 7 during heating. Our results showed that the concentration of OC released was similar for both the bicarbonate and phosphate buffer extraction reactions (Fig. S1 in the Supplement).

\subsection{Quantification of reactive Fe}

The concentration of reactive $\mathrm{Fe}$ in soils was determined by analyzing the $\mathrm{Fe}$ released during the DCB reduction process. After the reduction treatment, the supernatant of each sample was filtered using a $0.2 \mu \mathrm{m}$ syringe filter (cellulose acetate), and analyzed for Fe concentration by inductively coupled plasma-atomic emission spectroscopy (Varian-Vista AX CCD, Palo Alto, CA, USA) at an optical absorption wavelength of $259.9 \mathrm{~nm}$. All analyses are based on stan- 


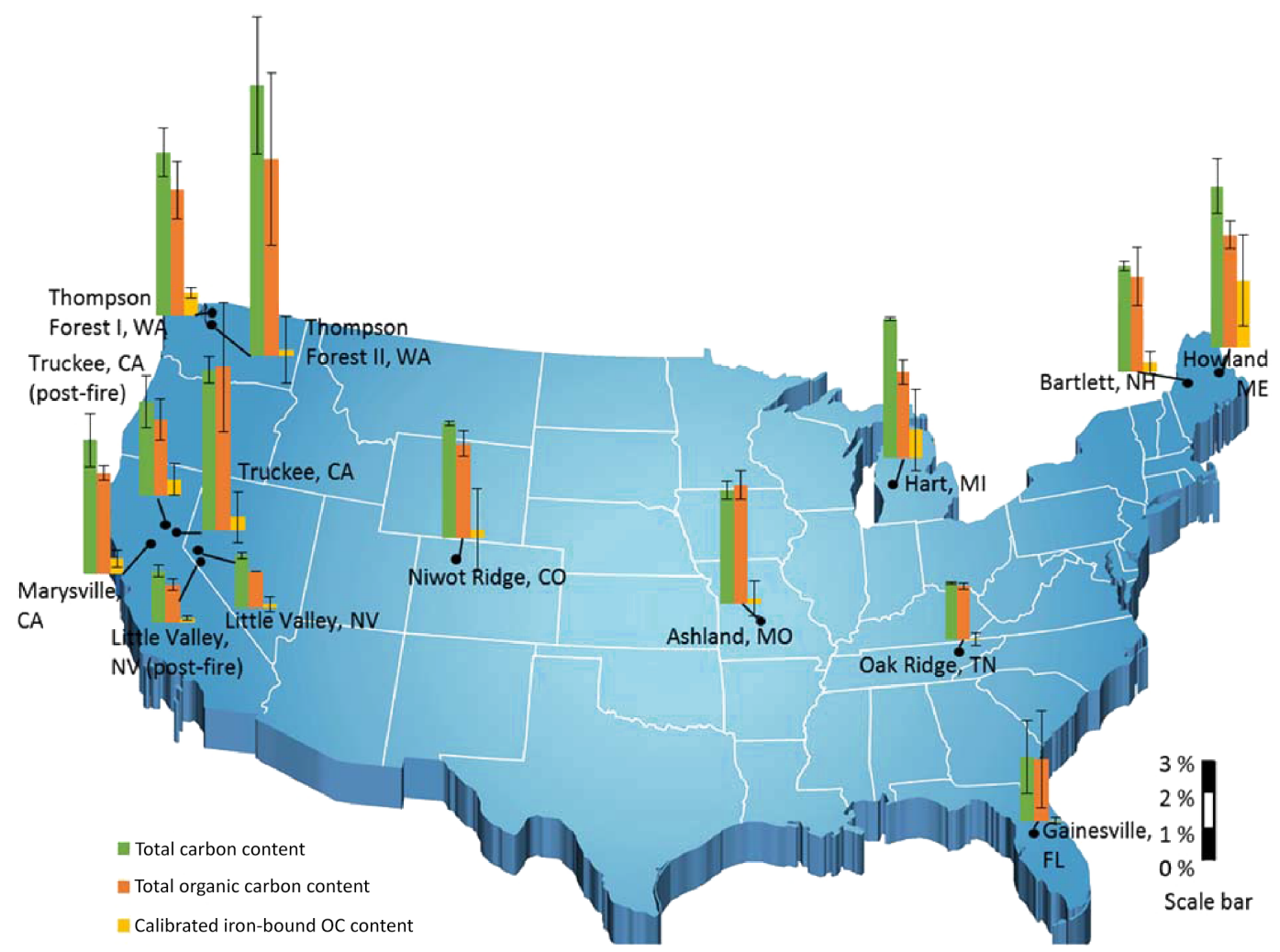

Figure 1. Concentrations of total carbon (TC), total organic carbon (TOC) and Fe-bound OC in 14 forest soils across the United States. TC, TOC, and Fe-bound OC contents are generally higher in soils with higher latitude (also shown in Fig. 3). Duplicate measurements were conducted for each of two plots in every forest site. Error bars represent standard deviation of measurements of four replicates for each forest site.

dard curves with $R^{2}>0.99$. The detection limit for $\mathrm{Fe}$ is $0.04 \mathrm{mg} \mathrm{g}^{-1}$ soil. The average coefficient of variation for the analysis of $\mathrm{Fe}$ is $25.8 \%$.

\subsection{Attenuated total reflectance-Fourier transform infrared spectroscopy (ATR-FTIR)}

ATR-FTIR analysis to characterize the molecular composition of OC was performed for original soil samples and residual soils after DCB extraction using a Thermo Scientific Nicolet 6700 FTIR (Waltham, MA). Dry soil samples were placed directly on the crystal and forced to contact well with the crystal. Spectra were acquired at the resolution of $4 \mathrm{~cm}^{-1}$ based on 100 scans. Data collection and baseline correction were accomplished using OMNIC software version 8.3.103.

\subsection{Near-edge $X$-ray absorption fine structure (NEXAFS) analysis}

For further characterization of chemical structure of organic matter, carbon (1s) K-edge NEXAFS analyses were performed for selected soil samples, i.e., for soils with the highest and lowest values of the fraction of Fe-bound $\mathrm{OC}$ to TOC. The soil particles were suspended in DI water and de- posited on an Au-coated silicon wafer attached to a $\mathrm{Cu}$ sample holder. Before analysis, samples were dried in a vacuum desiccator. The X-ray-based experiments were performed on the Spherical Grating Monochromator (SGM) beamline at the Canadian Light Source (Saskatoon, Canada; Regier et al., 2007). The energy scale was calibrated using citric acid (absorption at $288.6 \mathrm{eV}$ ). Major technical parameters and setup for the beamline include X-ray energy ranges $250-2000 \mathrm{eV}$, $45 \mathrm{~mm}$ planer undulator, $1000 \mu \mathrm{m} \times 100 \mu \mathrm{m}$ spot size, silicon drift detectors (SDD), a titanium filter before the sample, and entrance and exit slit gaps of 249.9 and $25 \mu \mathrm{m}$ (Gillespie et al., 2015). Carbon 1s spectra were acquired by slew scans from 270 to $320 \mathrm{eV}$ at $20 \mathrm{~s}$ dwell time and 20 scans per sample on a new spot. For data normalization, $I_{0}$ was collected by measuring the scatter of the incident beam from a freshly Au-coated Si wafer using SDD. Before the $I_{0}$ normalization, the pre-edge baseline was adjusted to near zero to remove the scatter in the sample data (Gillespie et al., 2015). 


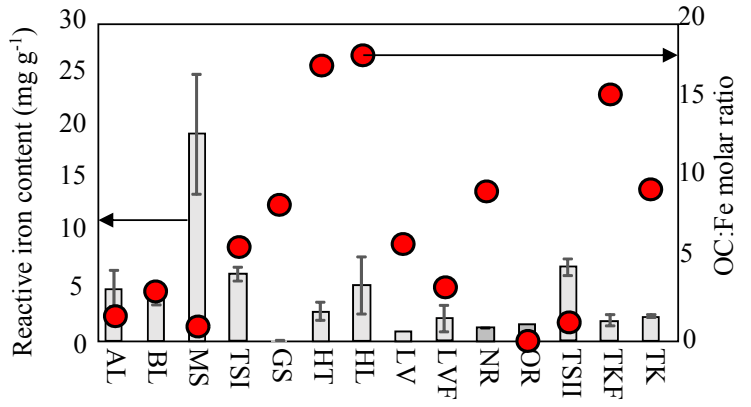

Figure 2. Concentration of reactive $\mathrm{Fe}$ and $\mathrm{OC}: \mathrm{Fe}$ molar ratio in the US forest soils.

\section{Results and discussion}

\subsection{Concentration of Fe-bound OC}

This study covered five major forest types in North America, including spruce-fir, pine, oak, chaparral, and maplebeech-birch forests distributed between 29 and $47^{\circ} \mathrm{N}$. For the 14 forest soils, TC concentrations ranged between $1.5 \pm 0.1$ and $8.3 \pm 2.1 \%$ (all percentages given are weightbased), and TOC concentrations ranged between $1.3 \pm 0.3$ and $6.2 \pm 2.9 \%$, which are comparable to values previously reported for North American forest soils (Wagai and Mayer, 2007; Wilson et al., 2013). Bicarbonate extraction-calibrated Fe-bound OC concentrations ranged from 0.3 to $1.9 \%$, with the fraction of Fe-bound $\mathrm{OC}$ to TOC $\left(f_{\mathrm{Fe}-\mathrm{OC}}\right)$ averaging $37.8 \pm 20.0 \%$ (Fig. 1, Table S1 in the Supplement). Forest HL (Maine) had the highest $f_{\mathrm{Fe}-\mathrm{OC}}$ of $57.8 \%$, while forests GS (Florida) and OR (Tennessee) had $f_{\mathrm{Fe}-\mathrm{OC}}$ values below detection limits (i.e., below $0.6 \%$ ). Based on an estimate that $1502 \mathrm{Pg}\left(\mathrm{Pg}=1 \times 10^{15} \mathrm{~g}\right)$ of TOC is stored in terrestrial soils (Scharlemann et al., 2014), scaling up these results to a global estimate would yield $538.5 \pm 271.5 \mathrm{Pg}$ of Fe-bound $\mathrm{OC}$ residing in terrestrial soils.

\section{2 $\mathrm{Fe}-\mathrm{OC}$ association}

The values of $f_{\mathrm{Fe}-\mathrm{OC}}$ were influenced not only by the concentration of reactive $\mathrm{Fe}$ but also by the type of association between $\mathrm{Fe}$ and OC. In this study, the concentration of reactive $\mathrm{Fe}$ in forest soils ranged from 0.1 to $19.3 \mathrm{mg} \mathrm{g}^{-1}$, which is low compared to values of reactive Fe of up to $180 \mathrm{mg} \mathrm{g}^{-1}$ reported previously (Wagai and Mayer, 2007; Wagai et al., 2013; Fig. 2). A Mollisol in forest site MS (California) had the highest concentration of reactive $\mathrm{Fe}$, while a Spodosol in forest site GS (Florida) had the lowest reactive Fe concentration. There was no significant correlation between $f_{\mathrm{Fe}-\mathrm{OC}}$ and the concentration of reactive $\mathrm{Fe}$ (Pearson Correlation Coefficient $r=-0.418, p=0.137$, Fig. S2). This suggests that the proportion of Fe-bound OC is not strongly controlled by the reactive $\mathrm{Fe}$ concentration.
The OC: Fe molar ratio ranged from 0.56 to 17.7 for all 14 soils, with a value between 1 and 10 for 10 soils (Fig. 2). Previous studies have suggested that the $\mathrm{OC}$ : Fe molar ratio can be used as an indicator for the type of association between $\mathrm{Fe}$ oxides and $\mathrm{OC}$, with lower values indicating sorptive interactions, while higher values indicate incorporation of OC within Fe oxides (Wagai et al., 2007; Guggenberger and Kaiser, 2003). The highest sorption capacity measured for $\mathrm{OC}$ onto $\mathrm{Fe}$ oxide corresponds to an $\mathrm{OC}: \mathrm{Fe}$ molar ratio $=1.0$ (Kaiser and Guggenberger, 2007), but by incorporation and co-precipitation of Fe oxide, the $\mathrm{OC}: \mathrm{Fe}$ molar ratio can reach much higher values (Guggenberger and Kaiser, 2003). With OC: Fe molar ratios generally between 1 and 10 for about two-thirds of the forest soils in this study, we propose that incorporation of $\mathrm{OC}$ into $\mathrm{Fe}$ oxides plays a major role in the accumulation of Fe-bound OC exceeding sorption by at least a factor of 1 to almost 20 (Wagai and Mayer, 2007; Lalonde, 2012). However, for the HT (Michigan), HL (Maine) and TKF (California) forest soils, the OC: Fe molar ratios were even higher than 10 , with a maximum value of 17.8 (Fig. 2), implying that incorporation of $\mathrm{OC}$ into $\mathrm{Fe}$ oxides dominated at these sites. Similar to $f_{\mathrm{Fe}-\mathrm{OC}}, \mathrm{OC}: \mathrm{Fe}$ ratios were not related to the concentration of reactive $\mathrm{Fe}$ and showed large variation for soils with a similar concentration of total reactive Fe (Fig. S2). This further indicates that the type of interactions between OC and Fe was not governed by the amount of Fe. The OC: Fe ratio is potentially regulated by the mineral phases of $\mathrm{Fe}$, as poorly crystalline Fe oxides have a higher capacity to bind with OC than crystalline Fe minerals (Eusterhues et al., 2014). When sorption dominates the interactions between $\mathrm{OC}$ and $\mathrm{Fe}, \mathrm{OC}$ : $\mathrm{Fe}$ can also be influenced greatly by the particle size and surface area of Fe oxides (Gu et al., 1995). Further investigations are needed to determine the factors that control the OC: Fe ratio, and also $f_{\mathrm{Fe}-\mathrm{OC}}$ values for soils. Nevertheless, the lack of (or poor) relationship shown here between the concentration of Fe-bound OC and Fe concentrations demonstrates the limitations associated with predicting and modeling the behavior of $\mathrm{C}$ in forest soils based on the $\mathrm{Fe}$ concentrations in soils alone.

\subsection{Spatial variance and ecogeographical factors}

We analyzed the influences of ecogeographical factors on the occurrence of Fe-bound OC in forest soils (Figs. 3, S3, S4). There was a significant correlation between the TOC concentration and latitude (Pearson correlation coefficient $r=0.619, p=0.018$ ), a pattern commonly observed due to lower microbial activity and turnover rates of $\mathrm{C}$ at higher, colder latitudes (Davidson and Janssens, 2006). The concentration of reactive $\mathrm{Fe}$, if excluding soil MS in California, was also significantly related to latitude $(r=0.824, p=0.001)$. Both concentrations of Fe-bound $\mathrm{OC}$ and $f_{\mathrm{Fe}-\mathrm{OC}}$ were also correlated with latitude $(r=0.523, p=0.053 ; r=0.525$, $p=0.054$ ). Among our samples, the soil in forest HL in 


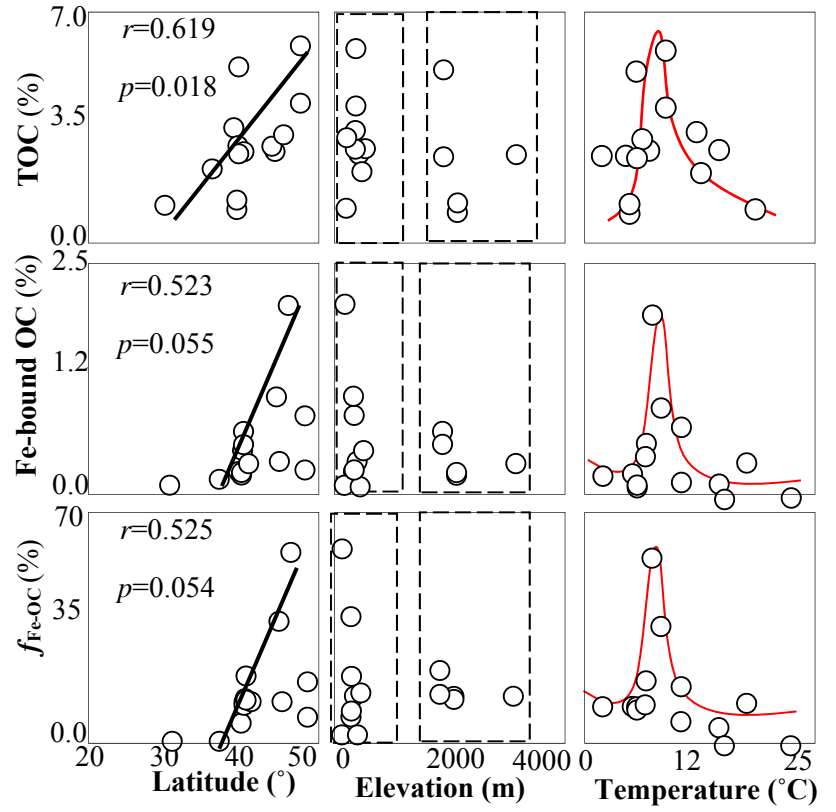

Figure 3. Relationships between TOC, concentration of Fe-bound OC, $f_{\mathrm{Fe}-\mathrm{TOC}}$ and ecogeographical parameters, including latitude, elevation (a.s.l.), and temperature (annual mean).

Maine, one of the three northernmost site with latitude of $45^{\circ}$, had the highest $f_{\mathrm{Fe}-\mathrm{OC}}$ of $57.8 \%$. In forest GS in Florida with lowest latitude of $29.7^{\circ}$, the $f_{\mathrm{Fe}-\mathrm{OC}}$ was below detection limits, possibly due to the low concentration of reactive $\mathrm{Fe}\left(0.08 \mathrm{mg} \mathrm{g}^{-1}\right)$. Hence, increase in latitude both increased concentrations of TOC in soil as well concentrations of Febound OC, suggesting increased interactions between Fe oxide and $\mathrm{OC}$ at higher latitudes. There were no clear trends in TOC or Fe-OC interactions with longitude. For elevation, we separated two groups of samples, with one group located below $1000 \mathrm{~m}$ (a.s.l.) and the other group above (mainly around 2000 and 4000 a.s.1.). Concentrations of TOC and Fe-bound $\mathrm{OC}$, however, were not significantly different between the two groups. There were no clear trends with precipitation either, although others have reported positive relationships between mean annual precipitation and soil TOC concentration at a global scale (Amundson, 2001). The concentration of Febound $\mathrm{OC}$ and $f_{\mathrm{Fe}-\mathrm{OC}}$ reached peak value with mean annual temperatures at $6.6^{\circ} \mathrm{C}$, with lower values both at higher and lower temperatures. Temperature dependence of Fe-bound OC can be regulated by effects of temperature on the mineral phase of $\mathrm{Fe}$ oxides and $\mathrm{OC}$ dynamics. Given that ferrihydrite can incorporate more $\mathrm{OC}$ than other crystalline $\mathrm{Fe}$ oxides, an increase in temperature favors the transformation of ferrihydrite to other crystalline iron oxides (Gnanaprakash et al., 2007; Zhao et al., 1994). However, an increase in temperature can also accelerate weathering of other minerals, and increased release of silicon can slow the transformation of ferrihydrite (Cornell et al., 1987; White and Blum, 1995). There

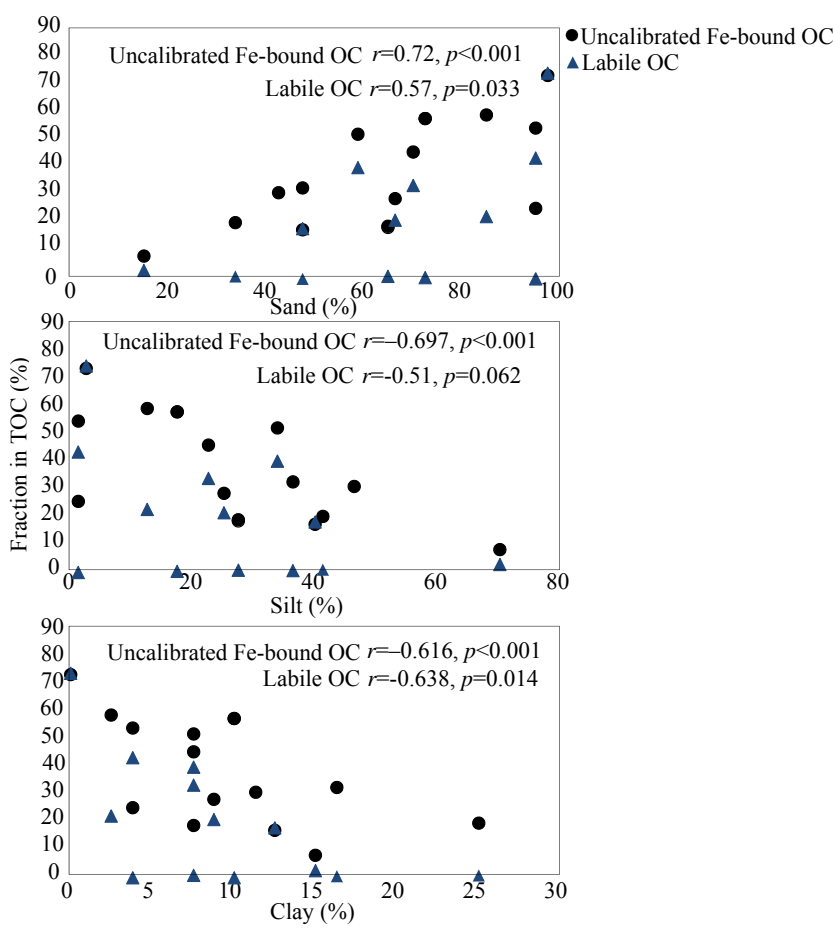

Figure 4. Relationships between the fractions of iron-bound organic carbon (uncalibrated for loss of labile OC) and labile organic carbon and soil texture (i.e., fractions of sand, silt, and clay in forest soils). Values of Pearson correlation coefficients $(r)$ and significance levels were given.

is also evidence that temperature can affect the chemical composition of soil OC substantially (Conant et al., 2011). For example, increased temperature decreased the content of oxidized functional groups, such as saccharides, which would consequently inhibit the interactions between OC and Fe oxides (Amelung et al., 1997). The overall pattern can result from combined effects of temperature on $\mathrm{Fe}$ mineral phase and OC transformation. Further investigations are required to elucidate the mechanism more accurately. Finally, the study covered seven major soil orders, i.e., Alfisols (sample number $n=3)$, Spodosols $(n=4)$, Mollisols $(n=1)$, Inceptisols $(n=2)$, Entisols $(n=2)$, Gelisols $(n=1)$, and Ultisols $(n=1)$. Although there are limited replications in many of these soil orders, the highest concentrations of Fe-bound $\mathrm{OC}$ were observed in Spodosols. Regarding $f_{\mathrm{Fe}-\mathrm{OC}}$, the highest values were also found in Spodosols, possibly indicating a particular importance of Fe-bound OC in this soil type which occupies $3.5 \%$ of US land areas and $4 \%$ of global ice-free land (Soil Survey Staff, 1999). However, due to the limited number of samples for each soil order, these findings warrant further confirmation. 


\subsection{Impact of soil physicochemical properties on $\mathrm{Fe}-\mathrm{OC}$ association}

Soil texture can potentially influence the accumulation of $\mathrm{Fe}$ bound OC. Figure 4 demonstrates that the fraction of noncalibrated Fe-bound OC showed a significant positive correlation with the fraction of sand $(r=0.72, p<0.001)$, and negative correlations with the fraction of silt $(r=-0.697$, $p<0.001)$ and clay $(r=-0.616, p<0.001)$. There were similar correlations between labile OC and the fractions of sand $(r=0.57, p=0.033)$, silt $(r=-0.51, p=0.062)$ and clay $(r=-0.638, p=0.014)$. However, the calibrated Febound OC had no significant correlation with any of the texture fractions (Fig. S5). These correlations indicate that the labile OC was mainly associated with the sand component of forest soils, but that the soil texture did not affect the Fe-bound OC. There is debate on the relative roles of sand, clay and silt in the stabilization of OC in soil (Percival et al., 2000; Six et al., 2002; Eusterhues et al., 2005; Vogel et al., 2014). Eusterhues et al. (2005) found a relationship between the resistance of organic matter to oxidative degradation and the clay concentration in soils, suggesting the importance of clay minerals in the stabilization and accumulation of soil OC. Reduced chemical potential of soil organic matter in small pores of clay-rich soils also limits microbial degradation and enhances its stabilization (Riedel and Weber, 2016). In contrast, Percival et al. (2000) found that the clay mineral fraction explained little of the variation in the accumulation of OC across a range of soil types in New Zealand. Vogel et al. (2014) found that less than $20 \%$ of clay mineral surfaces were covered by the sorption of OC, indicating that a limited proportion of clay mineral surface contributed towards the stabilization of OC. Our results suggest that the Fe oxide-mediated stabilization of OC was not related to the size/aggregation-based process, although the labile OC concentrations increased with the fraction of sand in the soils.

The Fe-OC association can also be influenced by the soil $\mathrm{pH}$, which affects the mineral phases of Fe oxides and their surface charge, and their interactions with OC. For our soil samples, the soil $\mathrm{pH}$ ranged from 4.1 to 6.3 , similar to measurements by Wagai and Mayer (2007) for North American soils. There was no significant correlation between the $f_{\mathrm{Fe}-\mathrm{OC}}$ and soil $\mathrm{pH}$, e.g., the HL (Maine) soil with $\mathrm{pH}$ of 4.4 had the highest $f_{\mathrm{Fe}-\mathrm{OC}}$ of $57.8 \%$, while the TS(II) (Washington) soil with a similar $\mathrm{pH}$ of 4.5 only had a $f_{\mathrm{Fe}-\mathrm{OC}}$ of $7.4 \%$. For soils with $\mathrm{pH}$ ranging from 4.9 to $5.8, f_{\mathrm{Fe}-\mathrm{OC}}$ did not change correspondingly. Contrastingly, values of $\mathrm{OC}$ : $\mathrm{Fe}$ molar ratios were significantly influenced by the soil $\mathrm{pH}$; except for one outlier sample of TS(II) (Washington) soil, there was a significant negative correlation between the $\mathrm{OC}: \mathrm{Fe}$ molar ratio and soil $\mathrm{pH}(r=-0.477, p=0.09$; Fig. S6). This may be due to the lower $\mathrm{pH}$ values favoring the complexation and precipitation of $\mathrm{Fe}$ with $\mathrm{OC}$, while higher $\mathrm{pH}$ favors sorptive interactions between Fe minerals and OC (Tipping et al., 2002). If comparing samples with a similar $\mathrm{pH}$, the soils with

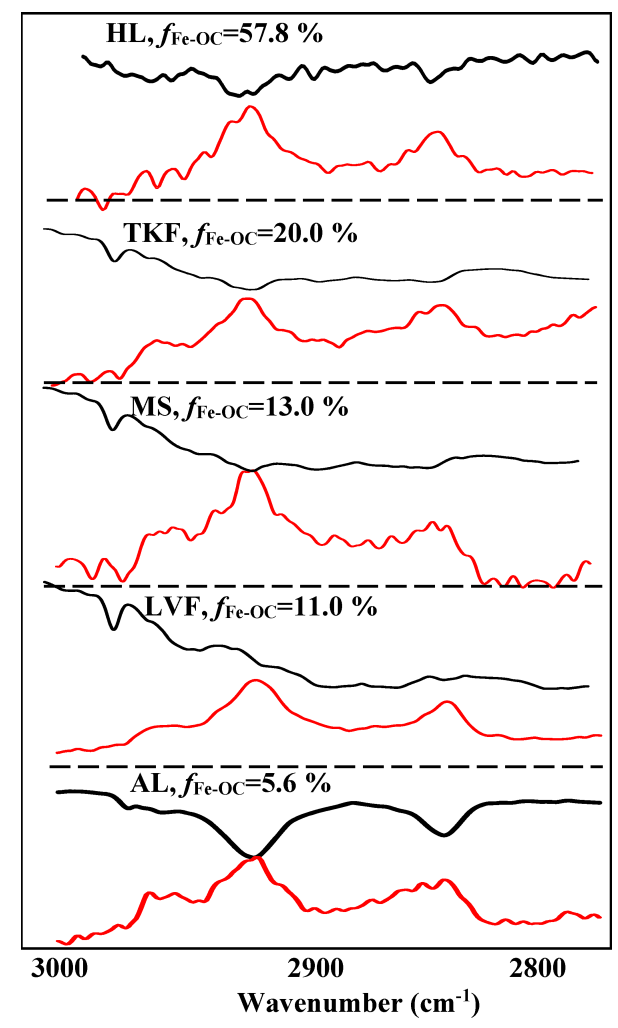

Figure 5. Attenuated total reflectance-Fourier transform infrared spectroscopy (ATR-FTIR) analysis for representative forest soils before (black line) and after Fe extraction (red line). All the spectra are background-calibrated. Among the 14 forest soils sampled in this study, we used five different forest soils, with $f_{\mathrm{Fe}-\mathrm{OC}}$ ranging $5.6-57.8 \%$.

higher TOC had higher OC:Fe molar ratios, e.g., the GS soil (TOC $=1.1 \%$ ) with $\mathrm{pH}$ of 4.7 had an $\mathrm{OC}:$ Fe molar ratio $=8.5$, while the HT (Michigan) soil $(\mathrm{TOC}=3.0 \%)$ with a similar $\mathrm{pH}$ of $4.7 \mathrm{had}$ an $\mathrm{OC}: \mathrm{Fe}$ molar ratio $=17.1$. This was consistent with Schwertmann and Latham (1986), who found that the major form of $\mathrm{Fe}$ would change from $\mathrm{FeO}_{x}$ to complexes with OC when there is higher OC supply.

\subsection{Molecular characteristics of Fe-bound OC}

The chemical composition of Fe-bound OC can be substantially different from non-Fe-bound OC (Adhikari and Yang, 2015) with broad implications on the $C$ biogeochemical cycles, although such differences so far have received limited attention. We analyzed the difference in chemical composition of Fe-bound OC compared to non-Fe-bound OC using ATR-FTIR analysis (Figs. 5, S7). Overall, there were limited fingerprint peaks for OC, because of the low concentration of TOC and technical challenge for analyzing whole soil particles with FTIR (Calderon et al., 2011; Simonetti et al., 2012). Reeves (2012) demonstrated that FTIR analysis of mineral soils in the ranges of $1600-1750$ and 
$2800-3000 \mathrm{~cm}^{-1}$ only can be used to study OC. Peaks in the range of $500-1200 \mathrm{~cm}^{-1}$ indicate the presence of clay or other Fe/Al minerals (Fig. S7; Madejova, 2003; Harsh et al., 2002; Parikh et al., 2014), such as kaolinite or montmorillonite at $850-1200 \mathrm{~cm}^{-1}$ (Madejova, 2003). Absorption at $850-1200 \mathrm{~cm}^{-1}$ can also be due to the presence of polysaccharides, but definitive identification of polysaccharides is not possible in the presence of minerals (Senesi et al., 2003; Tandy et al., 2010). The spectra in the range of 1600$1750 \mathrm{~cm}^{-1}$ normally contain fingerprint peaks for functional groups of amides, carboxylates and aromatics (Parikh et al., 2014), but we did not detect any significant peaks in this range. In the range of $2800-3000 \mathrm{~cm}^{-1}$, there were no significant peaks for the original soil samples, but after Fe extraction we detected significant peaks at 2850 and $2930 \mathrm{~cm}^{-1}$, which are characteristic for the presence of aliphatic carbon. The substantial differences in spectra before and after $\mathrm{Fe}$ extraction indicate that aliphatic OC was enriched in the residual soils after extraction. Other functional groups, such as aromatic carbon and hydrophilic functional groups, were more strongly associated with Fe minerals and removed during the Fe extraction, as hydrophilic functional groups can form inner-sphere coordination complexation with iron oxides, and aromatic carbon has electron donor-acceptor interactions with iron oxides (Gu et al., 1995; Axe and Persson, 2001). This result was consistent with a previous study using ultra-high-resolution mass spectrometry, showing the release of more aromatic carbon during the reductive dissolution of Fe oxides (Riedel et al., 2014). Analysis for the chemical nature of Fe-bound OC can be influenced by the potential reaction of natural organic matter with dithionite, which was not noticed in previous studies (Lalonde et al., 2012; Wagai and Mayer, 2007). The most likely reaction between dithionite and organic matter is the reduction of oxidized organic functional groups. Our recent study showed that dithionite could reduce quinone groups in natural organic matter (Adhikari et al., 2016). Most likely, other major functional groups, such as carboxylic and carbonyl functional groups, cannot be reduced by dithionite based on their reduction potentials (Bar-Even et al., 2012; Mayhew et al., 1978). Further investigations are needed to elaborate the detailed influences of dithionite reduction on the molecular properties of organic matter.

Furthermore, we analyzed the C1s NEXAFS spectra of two original, non-extracted soils with the highest and lowest values of $f_{\mathrm{Fe}-\mathrm{OC}}$, i.e., HL (Maine; $f_{\mathrm{Fe}-\mathrm{OC}}=57.8 \%$ ) and OR (Tennessee; $f_{\mathrm{Fe}-\mathrm{OC}}$ non-detectable; Fig. S8). Three major fingerprint peaks were detected for both soils, including peaks at $285.3,287.0$ and $288.7 \mathrm{eV}$, which correspond to aromatic carbon, aliphatic carbon and carboxylic carbon, respectively (Schumacher et al., 2005; Solomon et al., 2005; Lehmann et al., 2008). The OR (Tennessee) soil had a more substantial signal at $287.0 \mathrm{eV}$ than the HL (Maine) soil, indicating a higher aliphatic carbon concentration in the OR (Tennessee) soil compared to the HL (Maine) soil. The ra- tio of carboxylic carbon to aromatic carbon (peak height) was 3.8 for HL (Maine) and 1.0 for OR (Tennessee), suggesting that the HL (Maine) soil with higher $f_{\mathrm{Fe}-\mathrm{OC}}$ has relatively more carboxylic carbon compared to aromatic carbon. Hence, the C1s NEXAFS spectra suggest that the soil with the higher $f_{\mathrm{Fe}-\mathrm{OC}}$ has a higher concentration of carboxylic $\mathrm{C}$, while the soil with the lower $f_{\mathrm{Fe}-\mathrm{OC}}$ value has a higher aliphatic $\mathrm{C}$ concentration. This result is consistent with the comparison of ATR-FTIR spectra in soils before and after $\mathrm{Fe}$ extraction, providing evidence that $\mathrm{Fe}$ oxides are mainly associated with more hydrophilic and carboxylic carbon, while non-Fe-bound OC was more aliphatic.

To further investigate the relationships between soil OC and $\mathrm{Fe}$ minerals, we analyzed the stable $\mathrm{C}$ isotopic compositions $\left(\delta^{13} \mathrm{C}\right)$ of $\mathrm{Fe}$-bound vs. non-Fe-bound OC (i.e., the residual OC after DCB extraction). The $\delta^{13} \mathrm{C}$ for original soil samples ranged from -24.5 to $-27.5 \%$, and the values for non-Fe-bound OC were -25.1 to $-28.0 \%$. The $\delta^{13} \mathrm{C}$ for Febound $\mathrm{OC}$ was calculated by combined isotope-mass balance (Eq. 1):

$$
\begin{aligned}
\delta^{13} \mathrm{C}_{\mathrm{TOC}} \times \mathrm{TOC} & =\delta^{13} \mathrm{C}_{\text {labile }} \times \mathrm{OC}_{\text {labile }} \\
& +\delta^{13} \mathrm{C}_{\mathrm{Fe}-\mathrm{OC}}^{\prime} \times \mathrm{OC}_{\mathrm{Fe}}^{\prime} \\
& +\delta^{13} \mathrm{C}_{\mathrm{non}-\mathrm{Fe}-\mathrm{OC}} \times \mathrm{OC}_{\mathrm{non}-\mathrm{Fe}},
\end{aligned}
$$

where TOC is the concentration of total organic carbon, $\mathrm{OC}_{\text {labile }}$ is the concentration of labile $\mathrm{OC}$ (extractable by bicarbonate buffer), $\mathrm{OC}_{\text {non-Fe }}$ is the concentration of non-Febound $\mathrm{OC}$ (residual $\mathrm{OC}$ after Fe extraction), and $\mathrm{OC}_{\mathrm{Fe}}^{\prime}$ is the concentration of Fe-bound $\mathrm{OC}$ (excluded the labile $\mathrm{OC}$ ); $\delta^{13} \mathrm{C}_{\text {TOC }}$ is $\delta^{13} \mathrm{C}$ for bulk OC, $\delta^{13} \mathrm{C}_{\text {labile }}$ is $\delta^{13} \mathrm{C}$ for labile OC, $\delta^{13} \mathrm{C}_{\mathrm{Fe}-\mathrm{OC}}$ is $\delta^{13} \mathrm{C}$ for Fe-bound $\mathrm{OC}, \delta^{13} \mathrm{C}_{\text {non-Fe-OC }}$ is $\delta^{13} \mathrm{C}$ for non-Fe-bound OC. However, it is difficult to directly resolve the $\delta^{13} \mathrm{C}_{\text {labile }}$ and $\delta^{13} \mathrm{C}^{\prime} \mathrm{Fe}-\mathrm{OC}$ using this equation. We simplified it to Eq. (2):

$$
\begin{aligned}
& \delta^{13} \mathrm{C}_{\mathrm{Fe}-\mathrm{OC}} \\
& =\frac{\left(\delta^{13} \mathrm{C}_{\mathrm{TOC}} \times \mathrm{TOC}-\delta^{13} \mathrm{C}_{\mathrm{non}-\mathrm{Fe}-\mathrm{OC}} \times \mathrm{OC}_{\mathrm{non}-\mathrm{Fe}}\right)}{\mathrm{OC}_{\mathrm{Fe}}},
\end{aligned}
$$

where $\delta^{13} \mathrm{C}_{\mathrm{Fe}-\mathrm{OC}}$ is $\delta^{13} \mathrm{C}$ for Fe-bound $\mathrm{OC}$ (including the labile OC), $\delta^{13} \mathrm{C}_{\text {TOC }}$ is $\delta^{13} \mathrm{C}$ for bulk OC, $\delta^{13} \mathrm{C}_{\text {non-Fe-OC is } \delta^{13} \mathrm{C}}$ for non-Fe-bound $\mathrm{OC}$, TOC is the concentration of total organic carbon, $\mathrm{OC}_{\text {non-Fe }}$ is the concentration of non-Fe-bound $\mathrm{OC}$, and $\mathrm{OC}_{\mathrm{Fe}}$ is the concentration of Fe-bound $\mathrm{OC}$. The ${ }^{13} \mathrm{C}$ for Fe-bound OC was heaviest for the TKF (California) soil, with a value of $-23.0 \%$, and the lightest for the GS (Florida) forest at $-27.0 \%$. Across all study sites, Febound $\mathrm{OC}$ was relatively enriched in ${ }^{13} \mathrm{C}(1.5 \pm 1.2 \%$ o heavier) compared to the non-Fe-bound OC. However, there is also a contribution of labile OC to the Fe-bound OC, where labile $\mathrm{OC}$ is the $\mathrm{OC}$ extracted during the dithionite-absent extraction described earlier). The $\delta^{13} \mathrm{C}$ value for labile $\mathrm{OC}$ can 
be calculated using Eq. (3):

$\delta^{13} \mathrm{C}_{\text {labile }}$

$=\frac{\left(\delta^{13} \mathrm{C}_{\mathrm{TOC}} \times \text { TOC- } \delta{ }^{13} \mathrm{C}_{\text {non-labile }} \times \mathrm{OC}_{\text {non-labile }}\right)}{\mathrm{OC}_{\text {labile }}}$,

where $\delta^{13} \mathrm{C}_{\text {labile }}$ is $\delta^{13} \mathrm{C}$ for labile OC, $\delta^{13} \mathrm{C}_{\mathrm{TOC}}$ is $\delta^{13} \mathrm{C}$ for

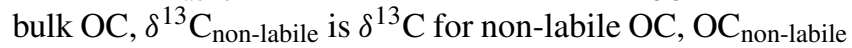
is the concentration of non-labile $\mathrm{OC}$, and $\mathrm{OC}_{\text {labile }}$ is the concentration of labile OC. Calculated values of $\delta^{13} \mathrm{C}_{\text {labile }}$ range from -23.4 to $-30.3 \%$, and were lighter than the values for

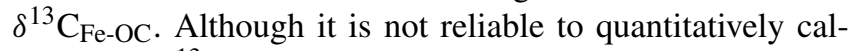
culate the $\delta^{13} \mathrm{C}$ for Fe-bound OC subtracting the influences of labile OC, these results indicate that the true value for $\delta^{13} \mathrm{C}_{\mathrm{Fe}-\mathrm{OC}}$ should be even somewhat heavier than the results presented in Figs. 6 and S9.

Our results demonstrate that $\mathrm{Fe}$-bound $\mathrm{OC}$ was enriched in ${ }^{13} \mathrm{C}$ compared to the non-Fe-bound $\mathrm{OC}$ in forest soils, which is consistent with results for sediments, where $\mathrm{Fe}$ bound $\mathrm{OC}$ was $1.7 \pm 2.8 \%$ o heavier than non-Fe-bound OC (Lalonde et al., 2012; Fig. 6a). Previous studies showed that ${ }^{13} \mathrm{C}$-enriched organic matter in sediments was enriched with $\mathrm{O}$ and $\mathrm{N}$ (due to the presence of compounds such as proteins and carbohydrate groups), while the microbial biomassderived lipid fraction was relatively ${ }^{13} \mathrm{C}$-depleted (Wang et al., 1998; Zelles et al., 1992). Similarly, compound-specific isotopic analyses have shown that oxygen- and nitrogen-rich constituents, such as cellulose, hemi-cellulose and amino acids, are ${ }^{13} \mathrm{C}$-enriched compared to hydrocarbons (Glaser, 2005), and these ${ }^{13} \mathrm{C}$-enriched oxygen- and nitrogen-rich compounds can associate with $\mathrm{Fe}$ oxide extensively through inner-sphere coordination interactions (Parikh et al., 2014). The value of $\Delta_{\mathrm{FeOC}-\mathrm{nonFeOC}}^{13}=\left(\delta^{13} \mathrm{C}_{\mathrm{Fe}-\mathrm{OC}}-\delta^{13} \mathrm{C}_{\mathrm{non}-\mathrm{Fe}-\mathrm{OC}}\right.$; difference in $\delta^{13} \mathrm{C}$ for Fe-bound $\mathrm{OC}$ and non-Fe-bound OC) was inversely correlated with the molar ratio of $\mathrm{OC}: \mathrm{Fe}$ $(r=-0.53, p=0.05$, Fig. $6 \mathrm{~b})$. These relationships suggest that the enrichment in ${ }^{13} \mathrm{C}$ was to some degree related to the $\mathrm{OC}: \mathrm{Fe}$ ratio. As discussed previously (Sect. 3.2), lower $\mathrm{OC}: \mathrm{Fe}$ ratios indicate an increased contribution from sorptive interactions of $\mathrm{OC}$ with $\mathrm{Fe}$ minerals as compared to incorporation of OC within iron oxides and OC, and these sorptive interactions between oxygen- and nitrogen-rich organic compounds and $\mathrm{Fe}$ oxide result in the enrichment of ${ }^{13} \mathrm{C}$ of $\mathrm{Fe}-$ bound $\mathrm{OC}$ vs. non-Fe-bound OC. Previous studies have attributed the stability of relatively labile and reactive compounds, such as amino acids and sugars, to their interactions with minerals (Schmidt et al., 2011), and our results demonstrated the importance of sorption to Fe minerals in increasing the stability of relatively reactive labile compounds.

Nitrogen $(\mathrm{N})$-containing functional groups are potentially important for the association between OC and Fe oxides, although the concentrations of $\mathrm{N}$ are much lower than $\mathrm{C}$ (Yang et al., 2012; Barber et al., 2014). The bulk soil contained $0.05-0.45 \% \mathrm{~N}$, while the non-Fe-bound component (i.e., the residual solid after DCB extraction) contained 0.06-
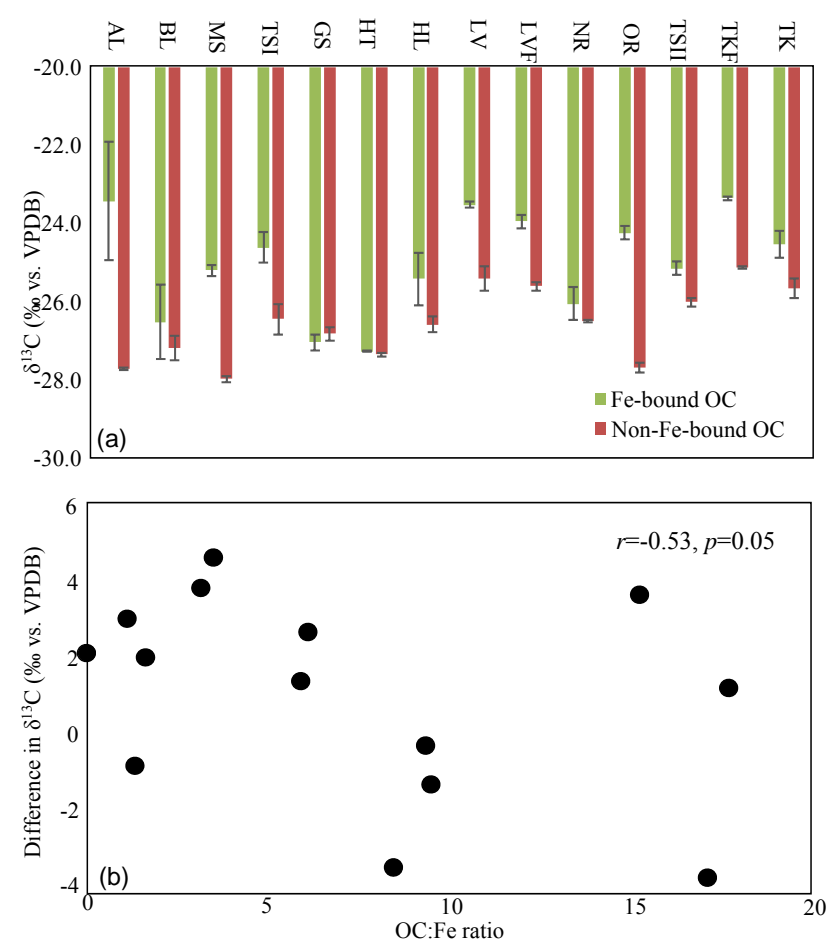

Figure 6. (a) $\delta^{13} \mathrm{C}$ of iron-bound and non-iron-bound organic carbon for 14 US forest sites. (b) Correlation between $\Delta_{\text {FeOC- }}^{13}$ and molar ratio of $\mathrm{OC}: \mathrm{Fe}$.

$0.32 \%$ N. Concentrations of Fe-bound N, calculated by difference, ranged up to $0.13 \%$. However, it is important to note that this number is based without a calibration for labile $\mathrm{N}$ that may be removed by the dithionite-free DCB extraction (data not available). There were significant correlations between $\mathrm{C}$ and $\mathrm{N}$ concentrations for both bulk soils $(r=0.847$, $p<0.001$ : Fig. S10) and the non-Fe-bound residual components $(r=0.858, p<0.001$ : Fig. S10), with molar C / N ratios of $14.2 \pm 2.6$ and $13.7 \pm 2.3$ for bulk and non-Fe-bound $\mathrm{OC}$, respectively. These $\mathrm{C} / \mathrm{N}$ values are essentially identical to a previously observed molar $\mathrm{C} / \mathrm{N}$ ratio $=14.3$ for a large set of worldwide soils samples (Cleveland and Liptzin, 2007), and a molar $\mathrm{C} / \mathrm{N}$ ratio $=14.4$ for OC-rich samples in China (Tian et al., 2010). This result suggests that C / N ratios for $\mathrm{Fe}$-bound $\mathrm{OC}$ did not differ from that of non-Febound $\mathrm{OC}$, assuming that the labile carbon did not have a substantially different $\mathrm{C} / \mathrm{N}$ ratio. Therefore, in contrast to the ${ }^{13} \mathrm{C}$ enrichment observed for Fe-bound $\mathrm{OC}$, the interactions with $\mathrm{Fe}$ minerals did not affect the $\mathrm{C} / \mathrm{N}$ ratio substantially.

\section{Conclusions}

Overall, this study provided a comprehensive investigation into the amount and characteristics of Fe-bound $\mathrm{OC}$ in forest soils as well as the impact of soil physicochemical proper- 
ties on Fe-bound OC. On average, Fe-bound OC contributed to $37.8 \%$ of TOC in forest soils, composing an important component of $\mathrm{C}$ cycles in terrestrial ecosystem. The $\mathrm{OC}: \mathrm{Fe}$ molar ratios in the forest soils studied ranged from 0.56 to 17.7, indicating the importance of both sorptive and incorporative interactions between $\mathrm{Fe}$ and $\mathrm{OC}$. $f_{\mathrm{Fe}-\mathrm{OC}}$ increased with latitude and reached the peak value for soils with an annual mean temperature of $6.6^{\circ} \mathrm{C}$, as a result of the temperature dependence of $\mathrm{Fe}$ mineral phase and $\mathrm{OC}$ transformation. Combined studies of FTIR, NEXAFS, and ${ }^{13} \mathrm{C}$ analysis revealed that $\mathrm{Fe}$-bound $\mathrm{OC}$ was less aliphatic, more carboxylic, and more enriched in ${ }^{13} \mathrm{C}$, compared to non-Fe-bound OC. Assuming Fe-bound $\mathrm{OC}$ is relatively stable, Fe oxides serve as a storage reservoir on decadal timescales for hydrophilic and carboxylic OC, which would be otherwise relatively more available for microbial degradation.

\section{The Supplement related to this article is available online at doi:10.5194/bg-13-4777-2016-supplement.}

Acknowledgements. This research was supported by DOE grant DE-SC0014275 and the University of Nevada-Reno Start-up Fund. NEXAF research described in this paper was performed at the Canadian Light Source, which is supported by CFI, NSERC, the University of Saskatchewan, the Government of Saskatchewan, WED Canada, NRC Canada, and CIHR. Sample collection was supported by a former EPA Science-To-Achieve-Results (STAR) grant (R833378). We also acknowledge the helpful comments from the editor and reviewers during the stage of quick reports.

Edited by: R. Bol

Reviewed by: two anonymous referees

\section{References}

Adhikari, D. and Yang, Y.: Selective stabilization of aliphatic organic carbon by iron oxide, Sci. Rep., 5, 11214, doi:10.1038/srep11214, 2015.

Adhikari, D., Poulson, S. R., Sumaila, S., Dynes, J. J., McBeth, J. M., and Yang, Y.: Asynchronous reductive release of iron and organic carbon from hematite-humic acid complexes, Chem. Geol., 430, 13-20, 2016.

Amelung, W., Flach, K. W., and Zech, W.: Climatic effects on soil organic matter composition in the great plains, Soil Sci. Soc. Am. J., 61, 115-123, 1997.

Amundson, R.: The carbon budget in soils, Annu. Rev. Earth Planet. Sc., 29, 535-562, 2001.

Axe, K. and Persson, P.: Time-dependent surface speciation of oxalate at the water-boehmite (gamma-AlOOH) interface: implications for dissolution, Geochim. Cosmochim. Ac., 65, 4481-4492, 2001.

Baldock, J. A. and Skjemstad, J. O.: Role of the soil matrix and minerals in protecting natural organic materials against biological attack, Org. Geochem., 31, 697-710, 2000.
Baldock, J. A., Masiello, C. A., Gelinas, Y., and Hedges, J. I.: Cycling and composition of organic matter in terrestrial and marine ecosystems, Mar. Chem., 92, 39-64, 2004.

Barber, A., Lalonde, K., Mucci, A., and Gélinas, Y.: The role of iron in the diagenesis of organic carbon and nitrogen in sediments: A long-term incubation experiment, Mar. Chem., 162, 1-9, 2014.

Bar-Even, A., Flamholz, A., Noor, E., and Milo, R.: Rethinking glycolysis: on the biochemical logic of metabolic pathways, Nat. Chem. Biol., 8, 509-517, 2012.

Calderon, F. J., Reeves III, J. B., Collins, H. P., and Paul, E. A.: Chemical differences in soil organic matter fractions determined by diffuse-reflectance mid-infrared spectroscopy, Soil Sci. Soc. Am. J., 75, 568-579, 2011.

Chorover, J. and Amistadi, M. K.: Reaction of forest floor organic matter at goethite, birnessite and smectite surfaces, Geochim. Cosmochim. Ac., 65, 95-109, 2001.

Cleveland, C. C. and Liptzin, D.: C:N :P stoichiometry in soil: is there a "Redfield ratio" for the microbial biomass?, Biogeochemistry, 85, 235-252, 2007.

Conant, R. T., Ryan, M. G., Agren, G. I., Birge, H. E., Davidson, E. A., Eliasson, P. E., Evans, S. E., Frey, S. D., Giardina, C. P., Hopkins, F. M., Hyvonen, R., Kirschbaum, M. U. F., Lavallee, J. M., Leifeld, J., Parton, W. J., Steinweg, J. M., Wallenstein, M. D., Wetterstedt, J. A. M., and Bradford, M. A.: Temperature and soil organic matter decomposition rates - synthesis of current knowledge and a way forward, Glob. Change Biol., 17, 33923404, 2011.

Cornell, R. M., Giovanoli, R., and Schindler, P. W.: Effect of silicate species on the transformation of ferrihydrite into goethite and hematite in alkaline media, Clay. Clay Miner., 35, 21-28, 1987.

Davidson, E. A. and Janssens, I. A.: Temperature sensitivity of soil carbon decomposition and feedbacks to climate change, Nature, 440, 165-173, 2006.

Eswaran, H., Reich, P. F., Kimble, J. M., Beinroth, F. H., Padmanabhan, E., and Moncharoen, P.: Global Climate Change and Pedogenic Carbonates, edited by: Lal, R., Lewis Publishers, Boca Raton, FL, USA, 1999.

Eusterhues, K., Hädrich, A., Neidhardt, J., Küsel, K., Keller, T. F., Jandt, K. D., and Totsche, K. U.: Reduction of ferrihydrite with adsorbed and coprecipitated organic matter: microbial reduction by Geobacter bremensis vs. abiotic reduction by Na-dithionite, Biogeosciences, 11, 4953-4966, doi:10.5194/bg-11-4953-2014, 2014.

Eusterhues, K., Rumpel, C., and Kogel-Knabner, I.: Organo-mineral associations in sandy acid forest soils: importance of specific surface area, iron oxides and micropores, Eur. J. Soil Sci., 56, 753 $763,2005$.

Gillespie, A. W., Phillips, C. L., Dynes, J. J., Chevrier, D., Regier, T. Z., and Peak, D.: Advances in using soft X-ray spectroscopy for measurement of soil biogeochemical processes, Adv. Agron., 133, 1-32, 2015.

Glaser, B.: Compound-specific stable-isotope (delta C-13) analysis in soil science, J. Plant Nutr. Soil Sci., 168, 633-648, 2005.

Gnanaprakash, G., Mahadevan, S., Jayakumar, T., Kalyanasundaram, P., Philip, J., and Raj, B.: Effect of initial pH and temperature of iron salt solutions on formation of magnetite nanoparticles, Mater. Chem. Phys., 103, 168-175, 2007. 
Gu, B. H., Schmitt, J., Chen, Z., Liang, L. Y., and McCarthy, J. F.: Adsorption and desorption of different organic-matter fractions on iron-oxide, Geochim. Cosmochim. Ac., 59, 219-229, 1995.

Guggenberger, G. and Kaiser, K.: Dissolved organic matter in soil: challenging the paradigm of sorptive preservation, Geoderma, 113, 293-310, 2003

Harsh, J. B., Chorover, J., and Nizeyimana, E.: Allophane and imogolite, Chap. 9, in: Soil Mineralogy with environmental applications, edited by: Dixon, J. B. and Schulze, D. G., Book Series SSSA No. 7, Madison, WI., 2002.

Johnson, D. W. and Curtis, P. S.: Effects of forest management on soil C and N storage: meta analysis, Forest Ecol. Manag., 140, 227-238, 2001.

Kaiser, K. and Guggenberger, G.: Sorptive stabilization of organic matter by microporous goethite: sorption into small pores vs. surface complexation, Eur. J. Soil Sci., 58, 45-59, 2007.

Kalbitz, K., Schwesig, D., Rethemeyer, J., and Matzner, E.: Stabilization of dissolved organic matter by sorption to the mineral soil, Soil Biol. Biochem., 37, 1319-1331, 2005.

Kalra, Y. P., Agrawal, H. P., Allen, E., Ashworth, J., Audesse, P., Case, V. W., Collins, D., Combs, S. M., Dawson, C., Denning, J., Donohue, S. J., Douglas, B., Drought, B. G., Flock, M. A., Friedericks, J. B., Gascho, G. J., Gerstl, Z., Hodgins, L., Hopkins, B., Horneck, D., Isaac, R. A., Kelly, P. M., Konwicki, J., Kovar, J., Kowalenko, G., Lutwick, G., Miller, R. O., Munter, R., Murchison, I., Neary, A., Neumann, R., Neville, M., Nolan, C. B., Olive, R., Pask, W., Pastorek, L., Peck, T. R., Peel, T., Ramakers, J., Reid, W. S., Rodd, V., Schultz, R., Simard, R., Singh, R. S., Sorrels, J., Sullivan, M., Tran, S., Trenholm, D., Trush, J., Tucker, M. R., Turcotte, E., Vanniekerk, A., Vijan, P. N., Villanueva, J., Wang, C., Warncke, D. D., Watson, M. E., Wikoff, L., and Yeung, P.: Determination of $\mathrm{pH}$ of soils by different methods - collaborative study, J. AOAC Int., 78, 310-324, 1995.

Krull, E. S., Baldock, J. A., and Skjemstad, J. O.: Importance of mechanisms and processes of the stabilization of soil organic matter for modelling carbon turnover, Funct. Plant Biol., 30, 207-222, 2003.

Lalonde, K., Mucci, A., Ouellet, A., and Gélinas, Y.: Preservation of organic matter in sediments promoted by iron, Nature, 483, 198-200, 2012.

Lehmann, J., Solomon, D., Kinyangi, J., Dathe, L., Wirick, S., and Jacobsen, C.: Spatial complexity of soil organic matter forms at nanometer scales, Nat. Geosci., 1, 238-242, 2008.

Madejova, J.: FTIR techniques in clay mineral studies, Vib. Spectrosc., 31, 1-10, 2003.

Mayer, L. M., Schick, L. L., Hardy, K. R., Wagai, R., and McCarthy, J.: Organic matter in small mesopores in sediments and soils, Geochim. Cosmochim. Ac., 68, 3863-3872, 2004.

Mayhew, S. G.: The redox potential of dithionite and $\mathrm{SO}^{-2}$ from equilibrium reactions with flavodoxins, methyl viologen and hydrogen plus hydrogenase, Eur. J. Biochem., 85, 535-547, 1978.

Mehra, O. P. and Jackson, M. L.: Iron oxide removal from soils and clays by a dithionite-citrate system buffered with sodium bicarbonate, in: National Conference on Clay, Clay Miner., 7, $317-$ 327,1960 .

Obrist, D.: Mercury distribution across 14 US forests, part II: patterns of methyl mercury concentrations and areal mass of total and methyl mercury, Environ. Sci. Technol., 46, 5921-5930, 2012.
Obrist, D., Johnson, D. W., Lindberg, S. E., Luo, Y., Hararuk, O., Bracho, R., Battles, J. J., Dail, D. B., Edmonds, R. L., Monson, R. K., Ollinger, S. V., Pallardy, S. G., Pregitzer, K. S., and Todd, D. E.: Mercury distribution across 14 US forests, part I: spatial patterns of concentrations in biomass, litter, and soils, Environ. Sci. Technol., 45, 3974-3981, 2011.

Obrist, D., Zielinska, B., and Perlinger, J. A.: Accumulation of polycyclic aromatic hydrocarbons (PAHs) and oxygenated PAHs (OPAHs) in organic and mineral soil horizons from four US remote forests, Chemosphere, 134, 98-105, 2015.

Parikh, S. J., Goyne, K. W., Margenot, A. J., Mukome, F. N. D., and Calderon, F. J.: Soil Chemical Insights Provided through Vibrational Spectroscopy, Adv. Agron., 126, 1-148, 2014.

Percival, H. J., Parfitt, R. L., and Scott, N. A.: Factors controlling soil carbon levels in New Zealand grasslands: Is clay content important?, Soil Sci. Soc. Am. J., 64, 1623-1630, 2000.

Reeves III, J. B.: Mid-infrared spectral interpretation of soils: Is it practical or accurate?, Geoderma, 189, 508-513, 2012.

Regier, T., Krochak, J., Sham, T. K., Hu, Y. F., Thompson, J., and Blyth, R. I. R.: Performance and capabilities of the Canadian Dragon: the SGM beamline at the Canadian Light Source, Nuclear Instruments \& Methods, in: Physics Research Section a, Accelerators Spectrometers Detectors and Associated Equipment, 582, 93-95, 2007.

Riedel, T., Iden, S., Geilich, J., Wiedner, K., Durner, W., and Biester, H.: Changes in the molecular composition of organic matter leached from an agricultural topsoil following addition of biomass-derived black carbon (biochar), Org. Geochem., 69, 52 60,2014

Riedel, T. and Weber, T. K.: The chemical potential of water in soils and sediments, Soil Sci. Soc. Am. J., 80, 79-83, 2016.

Riley, W. J., Maggi, F., Kleber, M., Torn, M. S., Tang, J. Y., Dwivedi, D., and Guerry, N.: Long residence times of rapidly decomposable soil organic matter: application of a multi-phase, multi-component, and vertically resolved model (BAMS1) to soil carbon dynamics, Geosci. Model Dev., 7, 1335-1355, doi:10.5194/gmd-7-1335-2014, 2014.

Scharlemann, J. P. W., Tanner, E. V. J., Hiederer, R., and Kapos, V.: Global soil carbon: understanding and managing the largest terrestrial carbon pool, Carbon Manag., 5, 81-91, 2014.

Schmidt, M. W. I., Torn, M. S., Abiven, S., Dittmar, T., Guggenberger, G., Janssens, I. A., Kleber, M., Kogel-Knabner, I., Lehmann, J., Manning, D. A. C., Nannipieri, P., Rasse, D. P., Weiner, S., and Trumbore, S. E.: Persistence of soil organic matter as an ecosystem property, Nature, 478, 49-56, 2011.

Schumacher, M., Christl, I., Scheinost, A. C., Jacobsen, C., and Kretzschmar, R.: Chemical heterogeneity of organic soil colloids investigated by scanning transmission X-ray microscopy and C-1s NEXAFS microspectroscopy, Environ. Sci. Technol., 39, 9094-9100, 2005.

Schwertmann, U. and Latham, M.: Properties of iron-oxides in some new caledonian oxisols, Geoderma, 39, 105-123, 1986.

Senesi, N., D'Orazio, V., and Ricca, G.: Humic acids in the first generation of EUROSOILS, Geoderma, 116, 325-344, 2003.

Simonetti, G., Francioso, O., Nardi, S., Berti, A., Brugnoli, E., Lugato, E., and Morari, F.: Characterization of humic carbon in soil aggregates in a long-term experiment with manure and mineral fertilization, Soil Sci. Soc. Am. J., 76, 880-890, 2012. 
Six, J., Callewaert, P., Lenders, S., De Gryze, S., Morris, S. J., Gregorich, E. G., Paul, E. A., and Paustian, K.: Measuring and understanding carbon storage in afforested soils by physical fractionation, Soil Sci. Soc. Am. J., 66, 1981-1987, 2002.

Sollins, P., Homann, P., and Caldwell, B. A.: Stabilization and destabilization of soil organic matter: Mechanisms and controls, Geoderma, 74, 65-105, 1996.

Solomon, D., Lehmann, J., Kinyangi, J., Liang, B. Q., and Schafer, T.: Carbon K-edge NEXAFS and FTIR-ATR spectroscopic investigation of organic carbon speciation in soils, Soil Sci. Soc. Am. J., 69, 107-119, 2005.

Soil Survey Staff: Soil taxonomy: A basic system of soil classification for making and interpreting soil surveys, 2nd Edn., Natural Resources Conservation Service, US Department of Agriculture Handbook, 436 pp., 1999.

Steffen, W., Noble, I., Canadell, J., Apps, M., Schulze, E. D., Jarvis, P. G., Baldocchi, D., Ciais, P., Cramer, W., Ehleringer, J., Farquhar, G., Field, C. B., Ghazi, A., Gifford, R., Heimann, M., Houghton, R., Kabat, P., Korner, C., Lambin, E., Linder, S., Mooney, H. A., Murdiyarso, D., Post, W. M., Prentice, I. C., Raupach, M. R., Schimel, D. S., Shvidenko, A., Valentini, R., and Terrestrial Carbon Working, G.: The terrestrial carbon cycle: implications for the Kyoto Protocol, Science, 280, 1393-1394, 1998.

Tandy, S., Healey, J. R., Nason, M. A., Williamson, J. C., Jones, D. L., and Thain, S. C.: FT-IR as an alternative method for measuring chemical properties during composting, Bioresour. Technol., 101, 5431-5436, 2010.

Tian, H., Chen, G., Zhang, C., Melillo, J. M., and Hall, C. A. S.: Pattern and variation of $\mathrm{C}: \mathrm{N}: \mathrm{P}$ ratios in China's soils: a synthesis of observational data, Biogeochemistry, 98, 139-151, 2010.

Tipping, E., Rey-Castro, C., Bryan, S. E., and Hamilton-Taylor, $\mathrm{J} .: \mathrm{Al}(\mathrm{III})$ and $\mathrm{Fe}(\mathrm{III})$ binding by humic substances in freshwaters, and implications for trace metal speciation, Geochim. Cosmochim. Ac., 66, 3211-3224, 2002.

Vogel, C., Mueller, C. W., Hoeschen, C., Buegger, F., Heister, K., Schulz, S., Schloter, M., and Koegel-Knabner, I.: Submicron structures provide preferential spots for carbon and nitrogen sequestration in soils, Nat. Commun., 5, 2947, doi:10.1038/ncomms3947, 2014.
Wagai, R. and Mayer, L. M.: Sorptive stabilization of organic matter in soils by hydrous iron oxides, Geochim. Cosmochim. Ac., 71, 25-35, 2007.

Wagai, R., Mayer, L. M., Kitayama, K., and Shirato, Y.: Association of organic matter with iron and aluminum across a range of soils determined via selective dissolution techniques coupled with dissolved nitrogen analysis, Biogeochemistry, 112, 95-109, 2013.

Wang, X. C., Druffel, E. R. M., Griffin, S., Lee, C., and Kashgarian, M.: Radiocarbon studies of organic compound classes in plankton and sediment of the northeastern Pacific Ocean, Geochim. Cosmochim. Ac., 62, 1365-1378, 1998.

Werner, R. A., Bruch, B. A., and Brand, W. A.: ConFlo III - An interface for high precision delta(13)C and delta(15)N analysis with an extended dynamic range, Rapid. Commun. Mass Sp., 13, 1237-1241, 1999.

White, A. F. and Blum, A. E.: Effects of climate on chemicalweathering in watersheds, Geochim. Cosmochim. Ac., 59, 17291747, 1995.

Wilson, B. T., Woodall, C.W., and Griffith, D.M.: Imputing forest carbon stock estimates from inventory plots to a nationally continuous coverage, Carbon Balance Manag., 8, 1-15, 2013.

Yang, W. H., Weber, K. A., and Silver, W. L.: Nitrogen loss from soil through anaerobic ammonium oxidation coupled to iron reduction, Nat. Geosci., 5, 538-541, 2012

Zelles, L., Bai, Q. Y., Beck, T., and Beese, F.: Signature fatty acids in phospholipids and lipopolysaccharides as indicators of microbial biomass and community structure in agricultural soils, Soil Biol. Biochem., 24, 317-323, 1992.

Zhao, J. M., Huggins, F. E., Feng, Z., and Huffman, G. P.: Ferrihydrite-surface-structure and its effects on phasetransformation, Clay. Clay Miner., 42, 737-746, 1994.

Zimmerman, A. R., Goyne, K. W., Chorover, J., Komarneni, S., and Brantley, S. L.: Mineral mesopore effects on nitrogenous organic matter adsorption, Org. Geochem., 35, 355-375, 2004. 